\title{
Non-invasive Methods for in vivo Determination of the Skin Barrier Function - Advantages of Confocal Raman Microspectroscopy
}

\section{E. Darvin, C. S. Choe, J. Schleusener, J. Lademann}

Maxim E. Darvin, https://orcid.org/0000-0003-1075-1994, Charité Universitätsmedizin Berlin, Chariteplatz 1, 10117 Berlin, Germany, maxim.darvin@charite.de

Chun Sik Choe, https://orcid.org/0000-0003-1633-7962, Kim II Sung University, Ryongnam-Dong, Taesong District, Pyongyang, DPR Korea, cs.choi@ryongnamsan.edu.kp

Johannes Schleusener, https://orcid.org/0000-0003-4088-6523, Charité - Universitätsmedizin Berlin, Charitéplatz 1, 10117 Berlin, Germany, johannes.schleusener@charite.de

Jürgen Lademann, https://orcid.org/0000-0003-1828-7460, Charité Universitätsmedizin Berlin, Charitéplatz 1, 10117 Berlin, Germany, juergen.lademann@charite.de

The physical barrier of the stratum corneum (SC) is provided by corneocytes and the lateral organization of intercellular lipids, which necessarily includes the orthorhombic organization phase. A review of methods used for in vivo non-invasive measurement of skin barrier function has been carried out and it has been shown that all currently used methods are indirect. The most popular method is the measurement of the transepidermal water loss (TEWL), which does not provide information on biophysical parameters responsible for the barrier function of the SC. It has been shown that confocal Raman microspectroscopy is the most suitable non-invasive method to determine the depth profile of the lateral organization of intercellular lipids, i.e. to study the skin barrier function in vivo.

Keywords: intercellular lipids, lateral organization, orthorhombic organization, hexagonal organization, lipid lamella, stratum corneum, Raman spectroscopy, TEWL.

Received: 18.04.2020 / Accepted: 29.05.2020 / Published: 31.08 .2020 This is an open access article distributed under the terms of Creative Commons Attribution License (CC-BY 4.0)

DOI: https://doi.org/10.18500/1817-3020-2020-20-3-171-177

\section{Introduction}

One of the main functions of the skin is the barrier function, i.e. protection against external physical and chemical influences, as well as against the penetration of pathogens into the body. The stratum corneum (SC), the uppermost continuously renewing layer of the epidermis, which represents a multifunctional system and serves as an effective physical barrier between the body and the environment, effectively protects against the penetration of pathogens (viruses, bacteria, allergens, microorganisms) into the "living" epidermis, and participates in the regulation of the water balance of the whole body.

The main components of the $\mathrm{SC}$ are keratin, lipids, water, natural moisturising factor molecules and antioxidants, whose concentrations are nonhomogeneously distributed in the SC depth [1] and represent a morpho-functional unity, participating directly and indirectly in the formation and continuous maintenance of the skin barrier function. The physical barrier of the $\mathrm{SC}$ is provided by corneocytes and the lateral organization of intercellular lipids (ICL) [2], which necessarily include the orthorhombic organization phase, a strictly ordered and most densely packed structure [3]. Lipids are strictly structured inside lamellas in form of membrane and are oriented mainly perpendicular to the skin surface, which directly determines their lateral organization [3]. In the SC of healthy human individuals, where the lipid composition is balanced, the orthorhombic phase of the lateral organization dominates, in which lipids are most tightly packed, highly ordered and stay predominantly in a trans-conformation. The ICL matrix is also called the lipid barrier or the $\mathrm{SC} /$ skin barrier. The thickness of the SC on the human forearm is $\approx 19 \mu \mathrm{m}$ [4] and varies depending on the skin area, being maximal on the palms and soles of the foot [5].

Methods for determining the lateral organization of ICL, which determines the skin barrier function [6], include wide angle and small-angle $\mathrm{X}$-ray scattering, electron diffraction, electron paramagnetic resonance spectroscopy, infrared spectroscopy and confocal Raman microspectroscopy (CRM). All these methods are suitable for measuring skin biopsies ex vivo, and only CRM has an advantage of measuring the lateral organization of ICL in vivo $[7,8]$.

\section{Barrier function of the SC is non-homogeneous in depth}

The question of how the orthorhombic and hexagonal phases of the lateral organization of ICL coexist and how they are distributed in the 
SC has remained unanswered for a long time. The first attempts to answer this question were made by Pilgram et al. [6] in an in vitro study of unfrozen human forearm SC tapes, obtained by applying tape stripping using the electron diffusion method to distinguish both phases of the lateral organization of ICL. The results showed that the hexagonal phase of the ICL organization prevails near the surface of the SC. The orthorhombic phase is characterized by a clearly defined maximum inside the $\mathrm{SC}$ at a depth corresponding to the 10-th tape application [6]. Yagi et al. [9], using the electron paramagnetic resonance spectroscopy method, confirmed in an in vitro experiment that the structural organization of the ICL matrix of the human SC is most dense at the intermediate $\mathrm{SC}$ depths. Later, using the combination of small-angle and wide-angle X-ray scattering methods, Doucet et al. [10] determined for the first time the distribution of the orthorhombic and hexagonal phases of the lateral ICL organization co-existing in the ICL lamellas of the human abdominal SC ex vivo. The results gave a complete picture for the entire SC thickness and showed that the orthorhombic phase of the lateral ICL organization prevails at intermediate $\mathrm{SC}$ depths, and a clear maximum is observed at a depth of $\approx 8-10 \mu \mathrm{m}(\approx 50 \%$ of the SC thickness). The authors have shown in an ex vivo experiment that the hexagonal phase of the lateral ICL organization prevails at the surface and at the boundary of the SC and stratum granulosum, which coincides with the data obtained earlier in an in vitro experiment [6]. Thus, the results of in vitro and ex vivo measurements obtained by different groups showed a non-homogeneous distribution of the lateral organization of ICL in the SC with predominance of the orthorhombic phase at a depth corresponding to $\approx 35-50 \%$ of the SC thickness $[6$, $10]$. Noninvasive in vivo measurements of the lateral organization of ICL in the SC became possible using CRM after the development of an algorithm for processing of Raman spectra [8], which is presented below.

\section{An overview of non-invasive methods} for in vivo assessment of the skin barrier function

In clinical practice, a dermatologist often only conducts a visual assessment of the state of the skin barrier function by indirect signs, based on practical recommendations to determine the severity of skin diseases. These can include those associated with impaired skin barrier function, such as psoriasis (PASI: Psoriasis Area and Severity Index) and atopic dermatitis (SCORAD: Scoring Atopic Dermatitis
Index) to determine a number of clinical parameters such as erythema, dryness and swelling of the skin. This approach is completely non-invasive, however is subjective, requires the experience of a physician, and can only be used to make a primary diagnosis and the assessment of the skin barrier function. Obviously, an objective study of the skin barrier function requires the use of accurate measurement methods [11].

A generally accepted non-invasive method, often used in vivo in dermatology and cosmetology to assess the skin barrier function, is the measurement of the transepidermal water loss (TEWL) [12]. This method measures a vapor pressure gradient near the skin surface by sensors located inside an open or closed chamber [13]. This method is indirect, but the correlation between the content of the orthorhombic phase of the ICL organization in the SC, which directly characterizes the skin barrier function, with the TEWL [14] confirmed the validity of this method. Thus, an increased TEWL characterizes the impaired skin barrier function. Presently, there is no alternative to the TEWL measurements in determining the skin barrier function in vivo, because the methods of direct analysis of the lateral ICL organization require the extraction of a biopsy and, thus, are invasive. Study of the SC by tape stripping is not a useful alternative, because tape stripping itself is a minimally invasive in vitro method that does not provide information in the entire SC. Despite the popularity of the TEWL measurement method, it has a number of serious practical shortcomings. These include the complexity of the measurement procedure and preparation for the measurement (the requirement of long-term acclimatization of a volunteer, the need for stable temperature and humidity inside the room, etc.), the large deviation of measurement results, the impossibility to measure TEWL after topical skin treatment with cosmetic or medical products (due to the presence of water in the formulation and due to the occlusion of the SC), as well as the impact of perspiration. It should also be kept in mind that water vapors contained in the exhaled air of people in the vicinity of the measurement device may influence the TEWL results.

The skin barrier function can be determined in vivo by the measurement of the superficial $\mathrm{pH}$ : an increase of $\mathrm{pH}$ in the skin surface is associated with a weakening of the SC barrier [15]. Usually, the $\mathrm{pH}$ value on the skin surface is measured with a $\mathrm{pH}-$ sensitive glass electrode. However, $\mathrm{pH}$ microscopy using $\mathrm{pH}$-sensitive fluorescent dyes and the subsequent measurement of fluorescence intensity and 
fluorescence lifetime decay are also possible [16]. The $\mathrm{pH}$ measurements on the skin surface are not time-consuming, well reproducible and often used in dermatology [15], however, the $\mathrm{pH}$ measurement is also an indirect method for measuring the skin barrier function.

An indirect indicator of the skin barrier function is the thickness of the $\mathrm{SC}$, which can be determined non-invasively and in vivo using imaging techniques such as, for instance, reflection confocal laser scanning microscopy [17], two-photon tomography [18] and optical coherence tomography [19]. These methods provide the large scanning area and the ability to visually identify inhomogeneity in the SC thickness. However, these devices are unable to perform structural analysis of the SC components, responsible for maintaining a skin barrier function.

Optical non-invasive methods based on Fouriertransform infrared spectroscopy [20] may serve for in vivo studies of the ICL organization. However, this method has one major limitation, strong absorption of radiation by water and as a result, the possibility to measure only the superficial SC depths [7], or the need to combine it with a minimally invasive procedure, removal of a part of the SC with tape stripping.

Recently, it has been proposed to use CRM to determine the skin barrier function to measure the counteraction of sodium lauryl sulfate penetration through the SC [21]. Despite the fact that the proposed method is also indirect and minimally invasive, the authors have shown a correlation with
TEWL measurements. Kikuchi et al. [7] found a correlation between the lateral ICL organization of the human SC, measured in vivo and ex vivo by Raman spectroscopy, with the ratio of the content of orthorhombic and hexagonal phases of the lateral ICL organization, measured ex vivo on the skin biopsy by using wide angle X-ray scattering. Thus, it is once again confirmed that the orthorhombic phase of the lateral ICL organization in the SC directly determines the barrier function of the skin and can be studied noninvasively and in vivo by CRM.

\section{Confocal Raman microspectroscopy for non-invasive in vivo determination of the skin barrier function}

In the range of $2820-3030 \mathrm{~cm}^{-1}$ the ratio of lipid-related Raman band intensities at $2880 \mathrm{~cm}^{-1}$ (anti-symmetric stretching mode of $\mathrm{CH}_{2}$ groups) and at $2850 \mathrm{~cm}^{-1}$ (symmetric stretching mode of $\mathrm{CH}_{2}$ groups) $I_{2880} / I_{2850}$ describes the lateral organization of lipids. In skin research, the main difficulty lies in the strong superposition of lipid- and keratin-related Raman bands in this spectral range. To solve this problem, an algorithm has been developed for separating the lipid and keratin contributions of the SC into the Raman band intensity. The algorithm uses known Raman spectra of model lipids and keratin and directly measured Raman spectra for the calculation of the parameters (Figure 1,a). The following formula for calculating the lateral organization of ICL in the SC was proposed [8]:

$$
\begin{gathered}
I_{2880} / I_{2850}=G E / K I=\left(\left(K_{2880}-P_{K}^{2880}\right) /\left(1-K_{2880} P_{L}^{2880}\right)\right) \cdot\left(\left(1-K_{2850} P_{L}^{2850}\right) /\left(K_{2850}-P_{K}^{2850}\right)\right), \\
\text { where } K_{2850}=J I / A D ; K_{2880}=H E / A D-\operatorname{directly~measured~from~the~Raman~spectra;~} \\
P_{K}^{2850}=M I / B D=0.150 \pm 0.025 ; P_{L}^{2850}=K I / C D=0.480 \pm 0.031, \\
P_{K}^{2880}=F E / B D=0.440 \pm 0.024 ; P_{L}^{2880}=G E / C D=0.320 \pm 0.026 .
\end{gathered}
$$

Further, using the developed algorithm, the distribution of lateral ICL organization in the human SC in vivo was determined for the first time (Figure 1, b). A higher $I_{2880} / I_{2850}$ value characterizes a greater number of lipid chains in trans-conformation, and thus a denser orthorhombic packing of lipids [8]. As can be seen from Figure 1, $b$, on the surface of the SC, the ratio of $I_{2880} / I_{2850}$ is $\approx 1.2$. Then, it increases with increasing SC depth and reaches a maximal value of $\approx 1.45$ (the highest content of the orthorhombic phase of the lateral ICL organization, the most dense and least permeable ICL package) at a depth of $20-40 \%$ of the SC thickness. Further, the $I_{2880} / I_{2850}$ ratio decreases and reaches a mini- mum value of $\approx 0.95$ (the highest content of the hexagonal phase of ICL organization, less dense and more permeable ICL packing) in the bottom of the SC.

In order to validate the CRM method, the lateral ICL organization has been measured in vivo in the skin of volunteers of two age groups (Figure 2,a) [22] and in comparison to the porcine ear skin ex vivo [23], which is known for lower skin barrier function [24] (Figure 2, b). The results show that differences are obvious not in the entire SC, but at certain SC depths: "older" skin is characterized with higher skin barrier function (more orthorhombic ICL phase) in comparison to "younger" skin at 


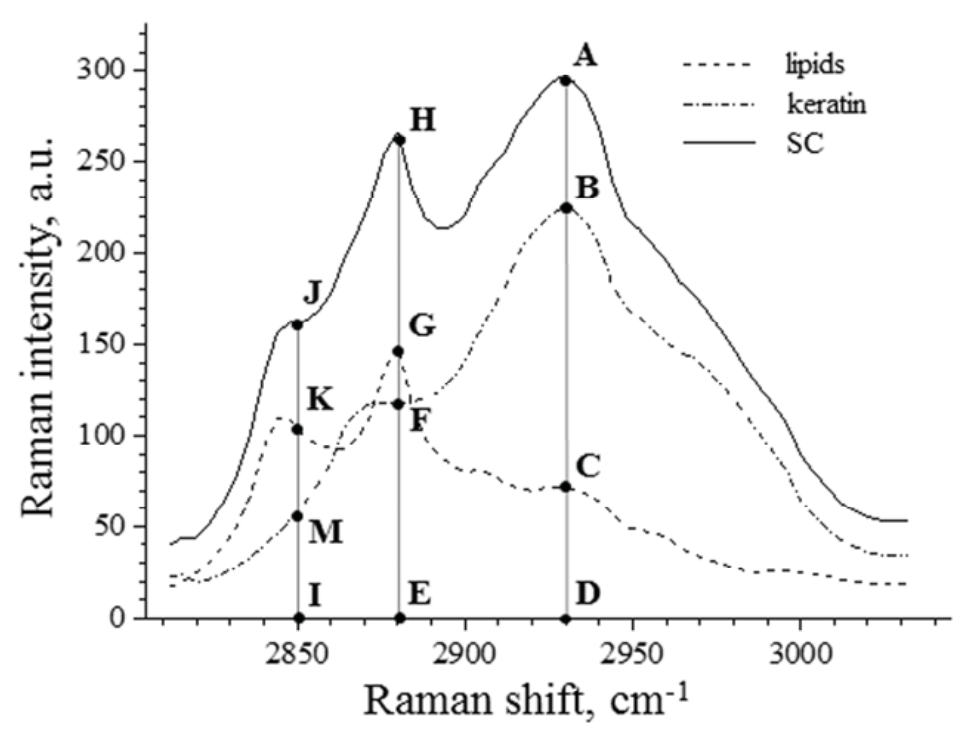

$a$

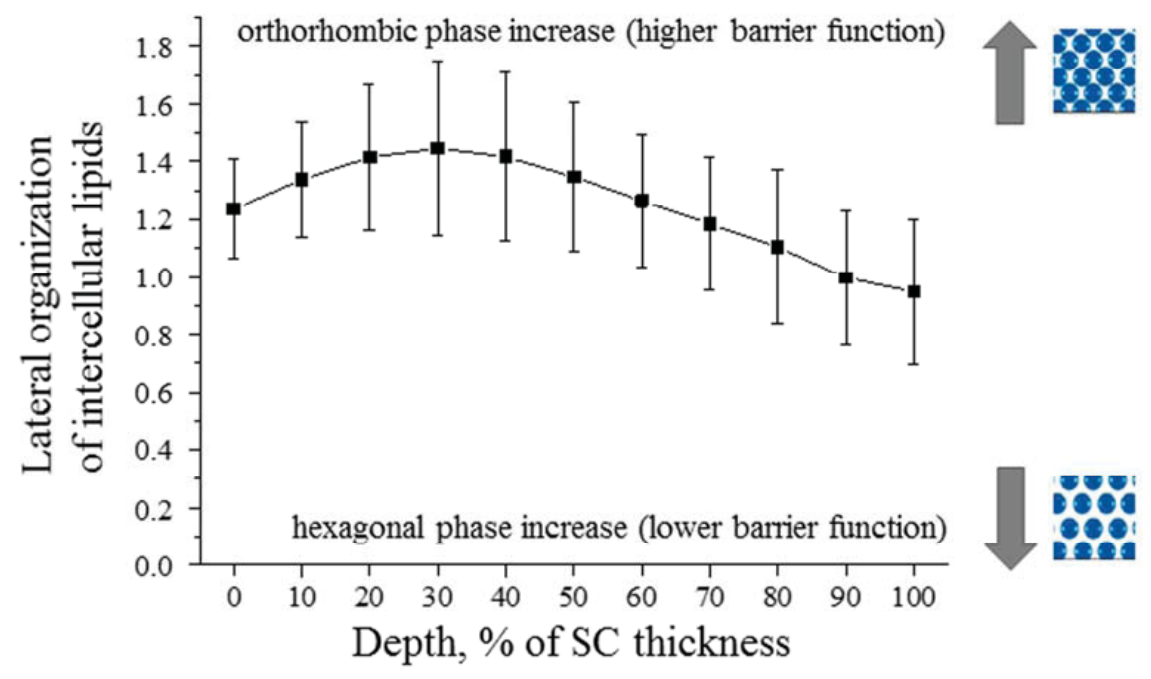

$b$

Fig. 1. Raman spectrum of human SC (depth $4 \mu \mathrm{m})$ in vivo (solid line), lipids (dashed line) and keratin (dash-dotted line) $(a)$ and the distribution of lateral ICL organization in the $\mathrm{SC}$, measured as $I_{2880} / I_{2850}(\mathrm{GE} / K I$ ratio in $(a)$ ) obtained in vivo in the skin of 6 volunteers (mean $\pm \mathrm{SD})(b)$. The SC thickness is normalized to $100 \%$. Figures adopted from [8].

/

20-30\% SC depth (Figure 2, a); porcine ear skin has lower skin barrier function (more hexagonal ICL phase) in comparison to human forearm skin at $10-50 \% \mathrm{SC}$ depth (Figure 2, b). This method can also be effectively applied to the treated skin in vivo, i.e. to analyze the influence of cosmetic and medical formulations on the barrier function related parameters of the SC [25]. The main limitation of the $\mathrm{CRM}$ is its costs and relatively long measurement and analysis time.

\section{Conclusions}

The lateral organization of lipids in the human SC measured in vivo is non-homogeneous and is characterized by a maximal content of the orthorhombic phase of the lateral ICL organization (the most dense and least permeable ICL package) at a depth of $20-40 \%$ of the SC thickness. In the superficial SC depths and in the bottom of the SC, the content of the hexagonal phase of the lateral ICL organization (less dense and more permeable ICL 


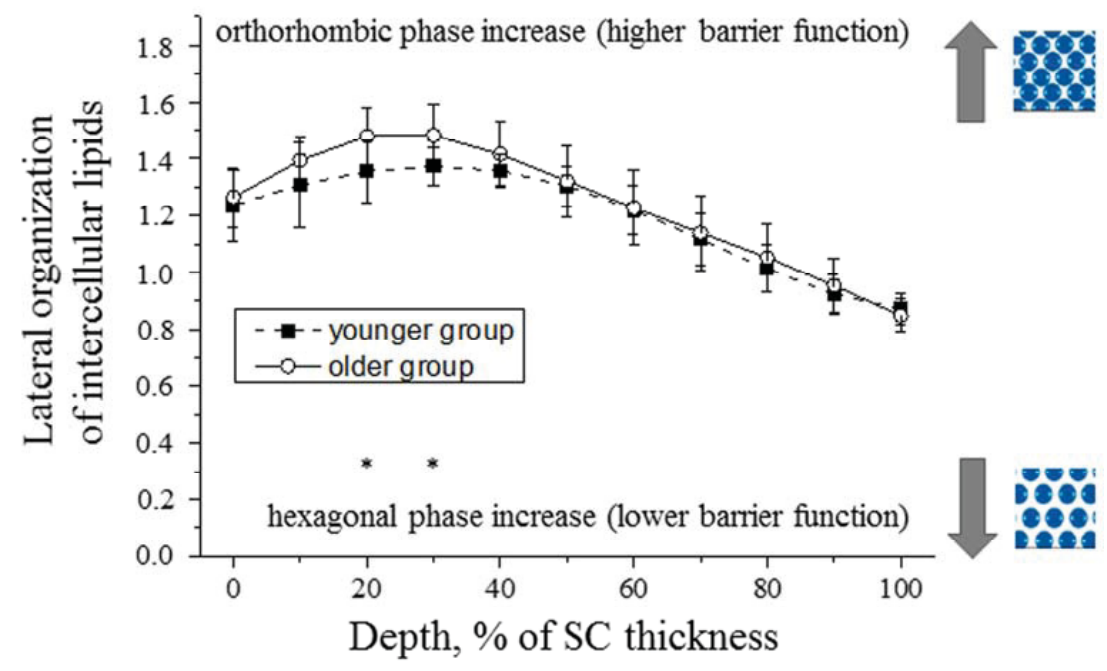

$a$

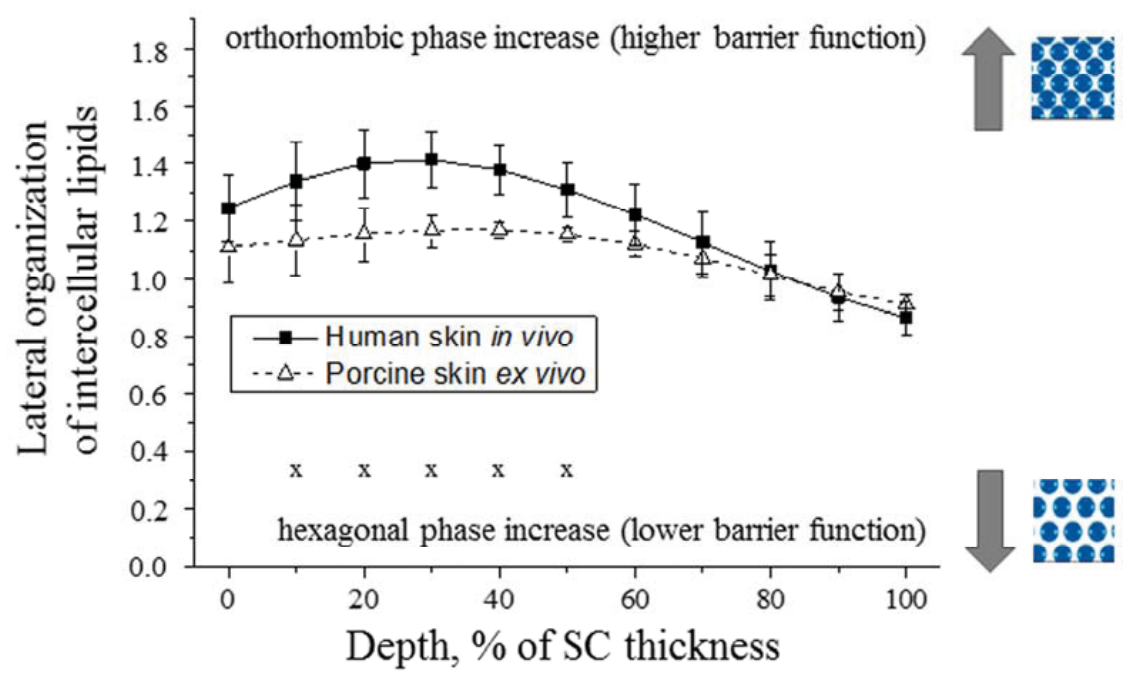

$b$

Fig. 2. The distribution of the lateral ICL organization in the SC obtained in vivo in the human skin of different age groups ("younger group": mean 29 y.o., 7 volunteers and "older group": mean 50 y.o., 4 volunteers) ( $a$ ) and comparison to porcine ear skin ex vivo (b). The SC thickness is normalized to $100 \%$. "*” and " $\mathrm{x}$ " represents modest $(p<0.1)$ and strong $(p<0.01)$ significant differences between the groups. Figures adopted from [22, 23].

/

package) is maximal. Changes of skin barrier function were observed at the certain depths of the SC. Confocal Raman microspectroscopy is an optimal non-invasive method for in vivo study of the skin barrier function provided by the SC.

\section{References}

1. Darvin M. E., Choe C. S., Schleusener J., Lademann J. Non-invasive depth profiling of the stratum corneum in vivo using confocal Raman microscopy considering the non-homogeneous distribution of keratin. Biomedical Optics Express, 2019, vol. 10, pp. 3092-3103.

2. Schmitt T., Neubert R. H. H. State of the art in stratum corneum research. Part II: hypothetical stratum corneum lipid matrix models. Skin Pharmacology and Physiology, 2020. DOI: $10.1159 / 000509019$

3. Van Smeden J., Janssens M., Gooris G. S., Bouwstra J. A. The important role of stratum corneum lipids for the cutaneous barrier function. Biochimica et Biophysica Acta, 2014, vol. 1841, pp. 295-313.

4. Choe C., Lademann J., Darvin M. E. Analysis of hu- 
man and porcine skin in vivo / ex vivo for penetration of selected oils by confocal Raman microscopy. Skin Pharmacology and Physiology, 2015, vol 28, pp. 318-330.

5. Nouveau-Richard S., Monot M., Bastien P., de Lacharriere O. In vivo epidermal thickness measurement: ultrasound vs. confocal imaging, Skin Research and Technology, 2004, vol. 10, pp. 136-140.

6. Pilgram G. S. K., Engelsma-van Pelt A. M., Bouwstra J. A., Koerten H. K. Electron diffraction provides new information on human stratum corneum lipid organization studied in relation to depth and temperature. Journal of Investigative Dermatology, 1999, vol. 113, pp. 403-409.

7. Kikuchi S., Aosaki T., Bito K., Naito S., Katayama Y. In vivo evaluation of lateral lipid chain packing in human stratum corneum. Skin Research and Technology, 2015, vol. 21, pp. 76-83.

8. Choe C., Lademann J., Darvin M. E. A depth-dependent profile of the lipid conformation and lateral packing order of the stratum corneum in vivo measured using Raman microscopy. Analyst, 2016, vol. 141, pp. 19811987.

9. Yagi E., Sakamoto K., Nakagawa K. Depth dependence of stratum corneum lipid ordering: a slow-tumbling simulation for electron paramagnetic resonance, Journal of Investigative Dermatology, 2007, vol. 127, pp. 895-859.

10. Doucet J., Potter A., Baltenneck C., Domanov Y. A. Micron-scale assessment of molecular lipid organization in human stratum corneum using microprobe X-ray diffraction. Journal of Lipid Research, 2014, vol. 55, pp. 2380-2388.

11. Utz S. R., Karakaeva A. V., Galkina E. M. Noninvasive evaluation of the barrier properties of the skin (review). Saratov Journal of Medical Scientific Research, 2014, vol. 10, pp. 512-517.

12. Antonov D., Schliemann S., Elsner P. Methods for the assessment of barrier function. Current Problems in Dermatology, 2016, vol. 49, pp. 61-70.

13. Fluhr J. W., Feingold K. R., Elias P. M. Transepidermal water loss reflects permeability barrier status: validation in human and rodent in vivo and ex vivo models. Experimental Dermatology, 2006, vol. 15, pp. 483-492.

14. Damien F., Boncheva M. The extent of orthorhombic lipid phases in the stratum corneum determines the barrier efficiency of human skin in vivo. Journal of Investigative Dermatology, 2010, vol. 130, pp. 611-614.

15. Proksch E. pH in nature, humans and skin. Journal of Dermatology, 2018, vol. 45, pp. 1044-1052.
16. Hanson K. M., Behne M. J., Barry N. P., Mauro T. M., Gratton E., Clegg R. M. Two-photon fluorescence lifetime imaging of the skin stratum corneum $\mathrm{pH}$ gradient. Biophysical Journal, 2002, vol. 83, pp. 16821690 .

17. Calzavara-Pinton P., Longo C., Venturini M., Sala R., Pellacani G. Reflectance confocal microscopy for in vivo skin imaging. Photochemistry and Photobiology, 2008, vol. 84, pp. 1421-1430.

18. Koehler M. J., Vogel T., Elsner P., Konig K., Buckle R., Kaatz M. In vivo measurement of the human epidermal thickness in different localizations by multiphoton laser tomography. Skin Research and Technology, 2010, vol. 16, pp. 259-264.

19. Li W. J., Li P., Fang Y. H., Lei T., Dong K., Zou J., Gong W., Xie S. S., Huang Z. Quantitative assessment of skin swelling using optical coherence tomography. Photodiagnosis and Photodynamic Therapy, 2019, vol. 26, pp. 413-419.

20. Boncheva M., Damien F., Normand V. Molecular organization of the lipid matrix in intact stratum corneum using ATR-FTIR spectroscopy. Biochimica et Biophysica Acta, 2008, vol. 1778, pp. 1344-1355.

21. Van Logtestijn M. D., Caspers P. J., Kezic S., Hoffman D. R., Koenig D. W., Ono M., Stamatas G. N., Tanaka R. J. Water resistance profile as a marker of skin barrier damage in atopic dermatitis patients. Journal of Dermatological Science, 2016, vol. 81, pp. 126-128.

22. Choe C., Schleusener J., Lademann J., Darvin M. E. Age related depth profiles of human stratum corneum barrier-related molecular parameters by confocal Raman microscopy in vivo. Mechanisms of Ageing and Development, 2018, vol. 172, pp. 6-12.

23. Choe C., Schleusener J., Lademann J., Darvin M. E. Human skin in vivo has a higher skin barrier function than porcine skin ex vivo - comprehensive Raman microscopic study of the stratum corneum. Journal of Biophotonics, 2018, vol. 11, pp. e201700355.

24. Caussin J., Gooris G. S., Janssens M., Bouwstra J. A. Lipid organization in human and porcine stratum corneum differs widely, while lipid mixtures with porcine ceramides model human stratum corneum lipid organization very closely. Biochimica et Biophysica Acta, 2008, vol. 1778, pp. 1472-1482.

25. Choe C., Schleusener J., Lademann J., Darvin M. E. In vivo confocal Raman microscopic determination of depth profiles of the stratum corneum lipid organization influenced by application of various oils. Journal of Dermatological Science, 2017, vol. 87, pp. 183-191.

\section{Cite this article as:}

Darvin M. E., Choe C. S., Schleusener J., Lademann J. Non-invasive Methods for in vivo Determination of the Skin Barrier Function - Advantages of Confocal Raman Microspectroscopy. Izv. Saratov Univ. (N. S.), Ser. Physics, 2020, vol. 20, iss. 3, pp. 171-177 (in Russian). DOI: https://doi.org/10.18500/1817-3020-2020-20-3-171-177 


\section{УДК 577.3}

Неинвазивные методы определения барьерной функции кожи in vivo преимущества конфокальной микроспектроскопии комбинационного рассеяния света

\section{М. Е. Дарвин, Ч. З. Чо, И. Шлойзенер, Ю. Ладеманн}

Дарвин Максим Евгеньевич, доктор теоретической медицины (Dr. rer. medic.), кандидат физико-математических наук, научный сотрудник кафедры физиологии кожи медицинского университета «Шаритэ», Берлин, Германия, maxim.darvin@charite.de

Чо Чун Зик, доктор философии (PhD), научный сотрудник кафедры медицинской физики университета имени Ким Ир Сена, Пхеньян, Корейская Народно-Демократическая Республика, cs.choi@ryongnamsan.edu.kp

Шлойзенер Иоханес, доктор теоретической медицины (Dr. rer. medic.), научный сотрудник кафедры физиологии кожи медицинского университета «Шаритэ», Берлин, Германия, johannes. schleusener@charite.de

Ладеманн Юрген, доктор инженерии (Dr.-ing.), профессор кафедры физиологии кожи медицинского университета «Шаритэ», Берлин, Германия, juergen.lademann@charite.de
Физический барьер рогового слоя кожи обеспечивается корнеоцитами и латеральной организацией внеклеточных липидов, которая обязательно включает в себя орторомбическую фазу организации. Обзор методов, используемых для неинвазивного in vivo измерения барьерной функции кожи показал, что все используемые в настоящее время методы являются косвенными. Наиболее популярным методом является измерение трансэпидермальной потери воды, который не дает информации о биофизических параметрах, определяющих барьерную функцию рогового слоя кожи. Показано, что метод конфокальной микроспектроскопии комбинационного рассеяния света является наиболее подходящим неинвазивным методом для определения распределения степени латеральной организации внеклеточных липидов по глубине рогового слоя, т.е. для изучения барьерной функции кожи в in vivo эксперименте.

Ключевые слова: внеклеточные липиды, степень латеральной организации, орторомбическая организация, гексагональная организация, липидная ламелла, роговой слой, спектроскопия комбинационного рассеяния света, трансэпидермальная потеря воды.

Поступила в редакцию: 18.04.2020 / Принята: 29.05.2020 / Опубликована: 31.08 .2020

Статья опубликована на условиях лицензии Creative Commons Attribution License (CC-BY 4.0)

\section{Образец для цитирования:}

Darvin M. E., Choe C. S., Schleusener J., Lademann J. Non-invasive Methods for in vivo Determination of the Skin Barrier Function - Advantages of Confocal Raman Microspectroscopy [Дарвин М. Е., Чо Ч. З., Шлойзенер И., Ладеманн Ю. Неинвазивные методы определения барьерной функции кожи in vivo-преимущества конфокальной микроспектроскопии комбинационного рассеяния света] // Изв. Сарат. ун-та. Нов. сер. Сер. Физика. 2020. Т. 20, вып. 3. С. 171-177. DOI: https://doi.org/10.18500/1817-3020-2020-20-3-171-177 